\title{
Spatiotemporal Attributes and Crop Loss Associated with Tan Spot Epidemics in Baby Lima Bean in New York
}

Sarah J. Pethybridge, ${ }^{\dagger}$ Frank S. Hay, and Adrienne Gorny, School of Integrative Plant Science, Plant Pathology \& Plant-Microbe Biology Section, Cornell University, Geneva, NY 14456; and Julie R. Kikkert, Cornell Cooperative Extension, Canandaigua, NY 14424

\begin{abstract}
Tan spot, caused by the pycnidial fungi Didymella americana and Boeremia exigua var. exigua, is a foliar disease affecting processing baby lima bean production in New York. Tan spot epidemics are prevalent, occur annually, and may result in substantial defoliation. The disease is controlled by the prophylactic application of fungicides to maximize green leaf area. Information on yield losses due to tan spot on baby lima bean yield and the benefits of fungicide applications is needed to justify investments in disease management. Four small-plot, replicated trials were conducted over 2 years in commercial baby lima bean fields to evaluate the efficacy of fungicides for tan spot control at Piffard and Leicester, NY. Applications of pyraclostrobin or boscalid significantly reduced tan spot incidence and severity compared with nontreated plots, and increased the number of leaves per stem. In 2016, the increase in green leaf area associated with fungicide application was also documented in canopy reflectance values at $830 \mathrm{~nm}$. Despite the decrease in tan spot incidence and corresponding increase in crop health obtained from fungicides, this

effect did not translate into significant increases in pod yield. This finding suggested that the relationship between green leaf area and yield is highly variable in baby lima bean. The spatial and spatiotemporal patterns of naturally occurring tan spot epidemics were also characterized in baby lima bean fields across western New York using disease incidence data collected in transects and grids. The spatial pattern of data collected in transects was analyzed using median runs analysis. Disease incidence data collected in two-dimensional grids were analyzed to quantify spatial pattern using spatial analysis by distance indices (SADIE). The association function of SADIE was used to quantify the spatiotemporal patterns of tan spot epidemics after crop emergence and at harvest. These findings suggested that tan spot is likely to initiate at relatively frequent, randomly positioned foci, and that subsequent, limited spread results in significant local aggregation. Hypotheses for inoculum sources and recommendations for tan spot control in baby lima bean fields in New York are discussed.
\end{abstract}

Baby lima bean (Phaseolus lunatus L.) crops have been grown traditionally for processing in the mid-Atlantic region of the United States but strong demand has provided growth opportunities and resulted in the establishment of new production areas in western New York. Baby lima bean production has increased in western New York from 160 ha in 2011 to 660 ha in 2014 in over 35 fields. Across the United States, 11,816 ha of baby lima bean were harvested in 2015, which were valued at approximately \$29 million (USDA-NASS 2016). In western New York, baby lima bean fields are established in early June by seed and grow for 10 to 12 weeks until harvest, when pods are green and succulent (Kee et al. 1997). Typical crops grown in rotation with baby lima bean are other processing vegetables (e.g., sweet corn, snap bean, table beet, and carrot) and field crops (e.g., dry bean, soybean, alfalfa, and field corn).

The productivity and expansion of the processing baby lima bean industry in western New York and other production areas has been limited by plant diseases affecting crop health (Kee et al. 1997). The most prevalent disease affecting pods is white mold caused by the fungus Sclerotinia sclerotiorum, which can cause substantial losses in disease-conducive years (Everts and Zhou 2007). Other important diseases of lima bean found elsewhere in the United States are pod rot caused by Phytophthora capsici (Kness et al. 2016) and downy mildew caused by P. phaseoli (Evans et al. 2007). Differences in dominant diseases, climatic conditions, and agronomic practices between western New York and other lima bean production areas mean that many of the recommendations for the control of white mold (Everts and Zhou 2004; Everts et al. 2002) and other diseases may not necessarily apply to this production region.

In further contrast to other lima bean production regions in the United States, the predominant foliar disease complex affecting baby lima bean in western New York is tan spot caused by Boeremia

${ }^{\dagger}$ Corresponding author: S. J. Pethybridge; E-mail: sjp277@ cornell.edu

Accepted for publication 22 September 2017.

(c) 2018 The American Phytopathological Society exigua var. exigua (Gorny et al. 2015) and Didymella americana (Gorny et al. 2016). Symptoms of tan spot are initially discrete, necrotic, circular lesions on leaves. These lesions rapidly coalesce to form larger necrotic areas. Older lesions have a lighter, tan-colored center in which pycnidia form (Gorny et al. 2016). Diseased leaves often abscise before complete necrosis develops. The disease may result in almost complete defoliation. Superficial, necrotic lesions on stems often initiate at nodes. B. exigua var. exigua has been reported to infect common bean, phasey bean, mung bean, field pea, soybean, and potato (Irinyi et al. 2009; Y. P. Li et al. 2012; Marcinkowska et al. 2005), many of which grow in the western New York, broadacre cropping rotations. Disease caused by B. exigua var. exigua has also been reported on species of Asteraceae, including chicory in Chile (Grinbergs et al. 2016) and pyrethrum in Australia (Jones et al. 2011). D. americana is also a cosmopolitan fungal pathogen reported on field crops grown in rotation with baby lima bean in western New York, including corn roots, soybean pods, and bean and wheat leaves (Aveskamp et al. 2009; Chen et al. 2015).

Depiction of the spatial characteristics of epidemics can provide quantitative information for inferring the relative role of inoculum sources initiating tan spot in baby lima bean, characterizing crop loss from the disease, and the design and implementation of sampling strategies (Hughes 1987, 2017; Madden et al. 2007; McRoberts et al. 2003). Techniques to quantify spatial patterns include point pattern and correlation-based techniques (Turechek and McRoberts 2013). Point pattern techniques convert spatial patterns into a nonscalar statistic and use fitting to appropriate distributions as evidence for aggregation or randomness at the level of the sampling unit or below (Hughes and Madden 1992, 1993; Madden and Hughes 1994, 1995, 1999; Turechek et al. 2011). Geostatistical techniques characterize spatial patterns at the scale of, or above, the sampling unit and quantify the degree of aggregation (Turechek and Madden 1999a,b). Examples of geostatistical techniques include ordinary runs (Gibbons and Chakraborti 2010; Madden et al. 1982) and spatial analysis by distance indices (SADIE) (B. Li et al. 2012; Perry 1995, 1998; Perry et al. 1999). Spatiotemporal analysis is also able to aid the development of hypotheses surrounding physical and biological mechanisms affecting plant disease epidemics (Madden 1989; Madden et al. 2007). 
For example, local spatial association characteristics can be compared over consecutive time periods to evaluate hypotheses concerning the role of external inoculum in disease spread (Winder et al. 2001).

Evaluation of the impact of tan spot on baby lima bean crop health and yield loss is paramount for the development of cost-effective crop management tactics that maximize returns and realize yield potential (Evans and Fischer 1999). For example, maximum attainable yield per unit of available resource is an essential benchmark to compare and contrast the impact of yield-reducing factors which may be further refined to identify and implement crop management practices (Passioura 2006; Soltani and Sinclair 2012). In the western New York baby lima bean production system, maximum attainable yield is undefined. The difference between maximum attainable yield and the attainable yield obtained under field conditions is often attributed to an integration of abiotic and biotic stresses such as plant diseases (James and Teng 1979; Johnson 1987; McRoberts et al. 2003; Savary et al. 2006). In the absence of robust information about crop loss caused by tan spot, many growers are risk averse and use multiple applications of fungicides for the control of tan spot and white mold in a standard program utilized on the majority of fields in New York. Therefore, the rapid development and implementation of cost-effective disease management strategies is vital for the continued success of the New York processing baby lima bean industry.

The primary objective of this study was to quantify the effect of tan spot on baby lima bean yield to assist in determining whether disease control measures are warranted. The relationship between green leaf area, tan spot intensity, and baby lima bean pod yield was also explored using near-infrared canopy reflectance. A secondary objective was to characterize the spatiotemporal characteristics of tan spot epidemics in commercial baby lima bean fields to develop hypotheses concerning sources of inoculum and means of disease spread. This information is essential for the development of a comprehensive understanding of the biotic and abiotic factors affecting baby lima bean production in New York.

\section{Materials and Methods}

Effect of fungicides on foliar disease and yield. Four small-plot, replicated trials were conducted in 2015 and 2016 in western New York to evaluate the effect of fungicides on tan spot incidence and severity and baby lima bean pod yield in commercial fields. In 2015, two trials were conducted in a field established from seed with approximately 10-ha blocks of varieties Cypress (trial 1) and Maestro (trial 2) at Piffard $\left(42^{\circ} 81^{\prime} \mathrm{N}, 77^{\circ} 85^{\prime} \mathrm{E}\right)$ planted on 20 June. In 2016, trials were conducted in approximately 5 -ha blocks established in the same field with varieties Cypress (trial 3) and 184-85 (trial 4) at Leicester $\left(42^{\circ} 79^{\prime} \mathrm{N}, 77^{\circ} 95^{\prime} \mathrm{E}\right)$ planted on 25 June. Both fields received similar, standard production practices, including fertilizer and herbicide applications, and were planted with a standard $0.76 \mathrm{~m}$ between rows. The time between planting and harvesting of baby lima bean fields in western New York generally varies between 12 and 15 weeks. Trials 1 and 2 received supplementary water (approximately $10 \mathrm{~mm}$ ) through overhead sprinklers on a central pivot at twice weekly intervals to maintain optimal growth. Trials 3 and 4 were located within a dryland crop. All fields had typical and similar cropping histories for this production region such as soybean, dry bean, snap bean, and corn.

Experimental design and treatments. In all trials, each of 20 plots consisted of four $6.1-\mathrm{m}$-long rows ( $3.05 \mathrm{~m}$ wide). Plots were separated by one row between and $1.2 \mathrm{~m}$ within row buffers that did not receive fungicides. Treatments were replicated five times within a completely randomized block design. Prior to the application of treatments (30 to 35 days after planting [DAP]), in-row plant density (number of plants per row meter) was assessed by counting the number of plants in $0.5-\mathrm{m}$ arbitrarily selected sections in the two inner rows of each plot ( $n=1-\mathrm{m}$ total row length that was assessed per plot). In-row plant density was evaluated as a potential covariate affecting tan spot incidence and severity, and crop yield. Treatments in all trials were (i) foliar disease control, consisting of two applications of active ingredient (a.i.) pyraclostrobin at $150 \mathrm{ml}$ a.i./ha (as Headline; BASF); (ii) pod disease control, consisting of two applications of boscalid at
$563.1 \mathrm{ml}$ a.i./ha (as Endura, BASF); (iii) foliar and pod disease control consisting of all four fungicide applications outlined in the former two treatments; and (iv) a nontreated control. Pyraclostrobin and boscalid were selected as the only two single-site mode-of-action fungicides registered for disease control in baby lima bean in New York. The timing of boscalid applications was restricted to later in the cropping season for pod disease control due to label restrictions. Fungicides were applied with a carbon dioxide-pressurized backpack sprayer fitted with a 0.96-m boom using four equally spaced flat-fan TJ 8002VS nozzles delivering a volume of 203.3 and 261.9 liters/ha in 2015 and 2016, respectively. In 2015, fungicides were applied at 51 and 58 (foliar disease control) and 65 and 72 (pod disease control) DAP. In 2016, treatments were applied at 52 and 59 (foliar disease control) and 66 and 72 (pod disease control) DAP.

Disease incidence. At 30 to $35 \mathrm{DAP}$, disease incidence on 20 randomly selected plants ([number of diseased leaves/total leaves] $\times$ 100 ) within $0.5-\mathrm{m}$ row sections of each of the two inner plot rows was assessed 2 days prior to the application of fungicides in both years. Assessments of disease incidence thereafter used individual stems as the sampling unit due to canopy closure and the inability to identify individual plants. On each stem, the number of diseased and healthy leaves was counted to quantify disease incidence. A single stem from each of 10 plants was systematically selected every $30 \mathrm{~cm}$ from an arbitrary starting point within each of the two inner plot rows $(n=20$ stems per plot), and an average calculated. A leaf was defined as diseased if at least one tan spot lesion was present. Disease incidence was assessed after the application of all treatments at 80 (trials 1 and 2) and 82 (trials 3 and 4) DAP. One leaf per stem ( $n=20$ leaves per plot) was also collected from the first node below the first flower on the raceme at the final disease assessment. Each leaf was photographed within $24 \mathrm{~h}$ in the laboratory, and disease severity was quantified using the image analysis application Leaf Doctor (Pethybridge and Nelson 2015) and averaged on a plot basis.

Fungal isolation frequency. The incidence of fungi associated with tan spot lesions in the nontreated plots within each of the four trials was quantified. Diseased leaves were collected arbitrarily ( $n=30$ per trial) at the final disease assessment ( 80 to 82 DAP). Leaves were stored at room temperature for up to $48 \mathrm{~h}$ before placement in individual glass petri dishes on fiberglass mesh suspended within sealed plastic trays that contained damp tissue to maintain high humidity. Trays were incubated at room temperature and observed for fungal growth after 10 days at low magnification $(\times 40)$. Individual pycnidia were transferred to potato dextrose agar (PDA; Hardy Diagnostics). After incubation, a single hyphal tip was excised using a sterile scalpel blade and transferred to a fresh PDA plate. Fungi were identified based on morphological characteristics and confirmed by comparison with respective type cultures for $D$. americana (Gorny et al. 2016) and B. exigua var. exigua (Gorny et al. 2015). The presence and incidence of other fungi was also recorded. Data were summarized as the percentage of fungi associated with the tan spot lesions on leaves within each trial.

Canopy reflectance. In trials 3 and 4 , the effect of treatment on green leaf area was also assessed within each plot at 82 DAP by measuring incident and reflected radiation with a hand-held, multispectral radiometer (MSR5; CropScan Inc.) at 485, 560, 660, 830, and $1,650 \mathrm{~nm}$. The radiometer was placed $2 \mathrm{~m}$ above the soil surface and positioned using a spirit level and support pole to enable measurements of canopy reflectance from a $0.97-\mathrm{m}^{2}$ area in the middle of each plot. This height was selected to ensure that the sensor's field of view at the soil level was several times the row spacing to minimize the coefficient of variation of reflectance measurements (Daughtry et al. 1982). Two canopy reflectance readings were made within each plot between 1300 and $1400 \mathrm{~h}$ (Eastern Time) to minimize variation from sun angle when incoming radiation was at least 500 watts $/ \mathrm{m}^{2}$. Percent reflectance was calculated as a percentage of the voltage value for the reflected radiation divided by the voltage value for the incident radiation at each of the wavelengths (Guan and Nutter 2001, 2004). The relationship between canopy reflectance in the near infrared (830 $\mathrm{nm}$ for the MSR5), crop health, green leaf area, and yield have been well described ( $\mathrm{Li}$ et al. 2014; Nilsson 
1995; Walter et al. 2015) in many other bean crops, including soybean (Ma et al. 2001) and dry bean (Gutiérrez-Rodriguez et al. 2006). Canopy reflectance measurements within each plot were averaged to provide a single reading per plot.

Yield. Evaluations of yield were conducted at 92 to 93 (trials 1 and 2 ) and 88 (trials 3 and 4) DAP. Plants were manually removed from two arbitrarily selected $0.5-\mathrm{m}$ row lengths within each of the two inner rows. Pods were manually separated from plants and weighed. Fifty pods from each plot were randomly subsampled and weighed to calculate the average weight of one pod.

Data analysis. The effect of treatment on tan spot incidence and severity, canopy reflectance at $830 \mathrm{~nm}$, and yield components (pod weight and average weight of one pod) was tested using generalized linear models, with treatment and replication used as the fixed and random effects, respectively. In-row plant density and disease incidence prior to fungicide application was tested as potential covariates for effects on variables measured during the cropping season. Exploratory data analysis using the Anderson-Darling goodness-of-fit test (Anderson and Darling 1954) detected significant differences among means between trials. The Fisher $F$ test (Markowski and Markowski 1990) also detected nonhomogeneous variances between trials. Therefore, the effect of treatment was analyzed on an individual trial basis. Means were separated with the Fisher's protected least significant difference test $(P=0.05)$.

Linear regression analyses modeled the relationship between canopy reflectance at individual wavelengths, ratios, the normalized difference vegetative index (NDVI) (Gamon and Surfus 1999), and difference vegetative index (DVI) (Broge and Leblanc 2001), and pod yield within trials 3 and 4 . The relationship was summarized according to significance ( $F$ statistic; $P<0.001$ ) and fit statistics, including the standard error of the estimate of $y$ (square root of the unexplained variation of $y$ ) and coefficient of determination $\left(R^{2}\right)$.

Analyses were conducted using the statistical software Genstat 17 (version 1; Hemel Hempstead, U.K.).

Spatiotemporal characteristics of tan spot epidemics. Data collection. Spatial patterns of tan spot epidemics were quantified by establishing multiple, linear transects and a single grid matrix in areas that did not receive fungicides within each of the four fields containing the two small-plot, replicated crop loss trials in 2015 (fields 1 and 2) and 2016 (fields 3 and 4). In 2015, tan spot incidence was quantified in six linear transects (each $20 \mathrm{~m}$ long) at 52 and 78
DAP. In 2016, tan spot incidence was quantified in four 20-m linear transects at 56 and 80 DAP. In both years, transects began at an arbitrarily selected point along a randomly chosen row.

In 2015, we assessed grid matrices that consisted of an area containing 10 rows each separated by $0.76 \mathrm{~m}$ and extended to a final length of $15 \mathrm{~m}$ at 52 and $78 \mathrm{DAP}$. The initial corner of each grid was selected arbitrarily and, along each of the 10 consecutive rows, one stem was arbitrarily chosen at $0.5-\mathrm{m}$ intervals. The total number of sampling units assessed within each grid at each time was 300. In 2016, grid matrices also consisted of 10 consecutive rows but one stem was assessed at each of 41 intervals at $0.5 \mathrm{~m}$ between stems at 56 and 80 DAP. The total number of sampling units within each grid at each assessment was 410 .

At each sampling location, tan spot incidence was assessed by defining one stem as the sampling unit. On each stem, the number of healthy and diseased leaves was counted. A diseased leaf was defined as having at least one tan spot lesion.

Spatial analysis-median runs. Median runs analysis was used to assess the spatial patterns of tan spot incidence within rows in the linear transects and the grid matrices at each assessment (Madden et al. 1982). For each dataset and time combination, median disease incidence was calculated across the sampling units. Sampling units with a disease incidence greater than or equal to the median were assigned a value of one and the remainder were assigned to zero. A run was defined as a succession of like events (i.e., stems with a median disease incidence above or below the median). A $Z$ statistic was used to determine whether the observed number of runs was significantly $(P \leq 0.05)$ different from the expected number of runs under the null hypothesis of randomness according to a one-sided test (Madden 1989; Madden et al. 1982).

Spatial analysis-SADIE. The spatial distribution of tan spot incidence expressed as a continuous percent variable was assessed within the grid matrices for all fields and assessment times using SADIE Shell software (Perry 1995, 1998; Perry et al. 1999). This technique uses a transportation algorithm to calculate the shortest distances needed to move spatially referenced data to depict "regular" and "crowded" spatial patterns using the same number of sampling units. These distances are then summed to calculate "distance to regularity" and "distance to crowding". Observed and calculated distances are compared with the maximum number of randomizations based on resampling of the locations of diseased measures. A one-sided test for aggregation was used to assess the deviation of the index of aggregation (ratio of expected to observed

Table 1. Efficacy of fungicides on tan spot incidence and severity, the number of leaves per stem, and yield components (total and average pod weight) in two trials conducted in baby lima bean fields at Piffard, NY in $2015^{\mathrm{u}}$

\begin{tabular}{|c|c|c|c|c|c|}
\hline Treatment $^{\mathrm{v}}$ & Tan spot incidence $(\%)^{\mathrm{w}}$ & Tan spot severity $(\%)^{\mathrm{w}}$ & Leaves per stem ${ }^{w}$ & Total weight of pods $(\mathrm{g})^{\mathrm{x}}$ & Average weight per pod $(g)^{x}$ \\
\hline \multicolumn{6}{|l|}{ Trial 1} \\
\hline Foliar & $38.1 \mathrm{~b}$ & $3.1 \mathrm{ab}$ & $10.2 \mathrm{a}$ & 1,247 & 3.8 \\
\hline Pod & $37.4 \mathrm{~b}$ & $1.9 \mathrm{~b}$ & $11.1 \mathrm{a}$ & 1,335 & 3.9 \\
\hline Foliar + Pod & $30.2 \mathrm{~b}$ & $1.6 \mathrm{~b}$ & $11.1 \mathrm{a}$ & 1,161 & 3.7 \\
\hline Nontreated & $77.3 \mathrm{a}$ & $3.9 \mathrm{a}$ & $5.0 \mathrm{~b}$ & 1,093 & 3.9 \\
\hline LSD $^{y}$ & 27.4 & 1.6 & 4.2 & na & na \\
\hline$P$ value & $<0.001$ & 0.03 & 0.004 & 0.387 & 0.384 \\
\hline $\mathrm{CV}(\%)^{\mathrm{z}}$ & 9.4 & 24.8 & 11.2 & 10.1 & 4.1 \\
\hline \multicolumn{6}{|l|}{ Trial 2} \\
\hline Foliar & $26.8 \mathrm{~b}$ & 2.0 & $10.3 \mathrm{a}$ & 1,007 & 3.8 \\
\hline Pod & $29 \mathrm{~b}$ & 1.9 & $11.4 \mathrm{a}$ & 1,031 & 3.9 \\
\hline Foliar + Pod & $25.4 \mathrm{~b}$ & 2.1 & $11.7 \mathrm{a}$ & 1,105 & 4.1 \\
\hline Nontreated & $63.4 \mathrm{a}$ & 3.7 & $7.2 \mathrm{~b}$ & 994 & 4.0 \\
\hline $\mathrm{LSD}^{\mathrm{y}}$ & 14.2 & na & 1.9 & na & na \\
\hline$P$ value & 0.004 & 0.289 & 0.001 & 0.813 & 0.565 \\
\hline $\mathrm{CV}(\%)^{\mathrm{z}}$ & 4.2 & 13.1 & 7.1 & 11.9 & 2.1 \\
\hline
\end{tabular}

u Means followed by the same letter are not significantly different $(P>0.05)$.

${ }^{v}$ Foliar = pyraclostrobin (as Headline) at $150 \mathrm{ml}$ a.i./ha at 51 and 58 days after planting (DAP); Pod = boscalid (as Endura) at $563.1 \mathrm{ml}$ a.i./ha at 65 and 72 DAP; Foliar + Pod $=$ all four applications described above.

${ }^{\mathrm{w}}$ Disease incidence $=($ number of diseased leaves/total number of leaves $) \times 100$ on 20 systematically selected stems per plot at 80 DAP. Disease severity $=$ percentage of leaf area affected by necrosis in each of 20 leaves per stem collected from the first node underneath the first flower on the raceme. Leaves per stem counted from the evaluation of disease incidence.

$x$ Weight of pods from 2-m row length per plot. Weight of one pod calculated from a 50-pod subsample. Pod yield components evaluated at 92 to 93 DAP

${ }^{y} \mathrm{LSD}=$ least significant difference $(P=0.05)$; na $=$ not applicable when $P>0.05$. Degrees of freedom for all comparisons $=19$.

${ }^{\mathrm{z}} \mathrm{CV}(\%)=$ coefficient of variation. 
distances to regularity) from the null hypothesis of no spatial dependence. An index of aggregation equal to one suggests a random spatial arrangement whereas, if the index is greater than one, there is evidence of an aggregated spatial pattern (Perry 1995, 1998; Perry et al. 1999).

Spatiotemporal analysis. The spatiotemporal characteristics of tan spot epidemics were analyzed using the data obtained from the grid matrices, with a null hypothesis of a lack of association between each of the spatial patterns. Local association $\left(\chi_{k}\right)$ was first quantified by performing comparisons between clustering indices for each of the two assessment times using SADIE. Overall association $(X)$ was then calculated as the mean of the local clustering indices obtained between each of the assessments within each grid matrix. Clustering indices represent the net distance that individuals need to move at each sampling unit to achieve regularity. Significance of $X$ was tested by the maximum number of randomizations with local association values for each sampling unit with a two-tailed test (Winder et al. 2001). Small-scale spatial autocorrelation was accounted for at both time periods using the Dutilleul adjustment (Dutilleul et al. 2008).

\section{Results}

Effect of fungicides on foliar disease and yield. In all trials, inrow plant density, the number of leaves on stems, and tan spot incidence were not significantly different across the trial area prior to the application of fungicides $(P>0.05$; data not shown).

Table 2. Efficacy of fungicides on tan spot incidence and severity, the number of leaves per stem, canopy reflectance at $830 \mathrm{~nm}$, and yield components (total and average pod weight) in two trials conducted in baby lima bean fields at Leicester, NY in $2016^{t}$

\begin{tabular}{|c|c|c|c|c|c|c|}
\hline Treatment ${ }^{u}$ & $\begin{array}{c}\text { Tan spot } \\
\text { incidence }(\%)^{\mathrm{v}}\end{array}$ & $\begin{array}{c}\text { Tan spot } \\
\text { severity }(\%)^{v}\end{array}$ & Leaves per stem ${ }^{v}$ & $\begin{array}{c}\text { Canopy reflectance } \\
(830 \mathrm{~nm})^{\mathrm{w}}\end{array}$ & $\begin{array}{l}\text { Total weight } \\
\text { of pods }(\mathrm{g})^{\mathrm{x}}\end{array}$ & $\begin{array}{l}\text { Average weight } \\
\text { per pod }(g)^{\mathrm{x}}\end{array}$ \\
\hline \multicolumn{7}{|l|}{ Trial 3} \\
\hline Foliar & $4.4 \mathrm{~b}$ & $4.5 \mathrm{~b}$ & $10.6 \mathrm{c}$ & $41.9 \mathrm{a}$ & 864 & 3.3 \\
\hline Pod & $4.2 \mathrm{~b}$ & $2.2 \mathrm{c}$ & $12.5 \mathrm{~b}$ & $41.2 \mathrm{a}$ & 572 & 3.0 \\
\hline Foliar + Pod & $3.2 \mathrm{~b}$ & $1.2 \mathrm{c}$ & $13.8 \mathrm{a}$ & $42.1 \mathrm{a}$ & 724 & 3.3 \\
\hline Nontreated & $16.3 \mathrm{a}$ & $9.0 \mathrm{a}$ & $8.2 \mathrm{~d}$ & $36.1 \mathrm{~b}$ & 668 & 3.3 \\
\hline LSD $^{y}$ & 2.7 & 2.2 & 1.1 & 1.7 & na & na \\
\hline$P$ value & $<0.001$ & $<0.001$ & $<0.001$ & $<0.001$ & 0.086 & 0.089 \\
\hline $\mathrm{CV}(\%)^{\mathrm{z}}$ & 18.3 & 11.6 & 2.5 & 3.9 & 8.1 & 2.0 \\
\hline \multicolumn{7}{|l|}{ Trial 4} \\
\hline Foliar & $2.6 \mathrm{~b}$ & $2.4 \mathrm{~b}$ & $20 \mathrm{a}$ & 53.4 & 1,320 & 3.4 \\
\hline Pod & $4.6 \mathrm{~b}$ & $2.2 \mathrm{~b}$ & $19.6 \mathrm{a}$ & 55.5 & 1,568 & 3.3 \\
\hline Foliar + Pod & $1.9 \mathrm{~b}$ & $2.0 \mathrm{~b}$ & $21.3 \mathrm{a}$ & 56.1 & 1,460 & 3.6 \\
\hline Nontreated & $25.7 \mathrm{a}$ & $8.3 \mathrm{a}$ & $16 \mathrm{~b}$ & 52.6 & 1,660 & 3.5 \\
\hline $\mathrm{LSD}^{\mathrm{y}}$ & 5.6 & 2.3 & 3.1 & na & na & na \\
\hline$P$ value & $<0.001$ & $<0.001$ & 0.004 & 0.117 & 0.761 & 0.249 \\
\hline $\mathrm{CV}(\%)^{\mathrm{z}}$ & 25.2 & 27.2 & 2.1 & 1.4 & 25.5 & 5.7 \\
\hline
\end{tabular}

${ }^{\mathrm{t}}$ Means followed by the same letter are not significantly different $(P>0.05)$.

${ }^{u}$ Foliar $=$ pyraclostrobin (as Headline) at $150 \mathrm{ml}$ a.i./ha at 52 and 59 days after planting (DAP); Pod = boscalid (as Endura) at $563.1 \mathrm{ml}$ a.i./ha at 66 and $72 \mathrm{DAP}$; Foliar + Pod $=$ all four applications described above.

${ }^{\vee}$ Disease incidence $=($ number of diseased leaves/total number of leaves $) \times 100$ on 20 systematically selected stems per plot at 82 DAP. Disease severity $=$ percentage of leaf area affected by necrosis in each of 20 leaves per stem collected from the first node underneath the first flower on the raceme. Leaves per stem counted from the evaluation of disease incidence.

${ }^{\text {w }}$ Average of two canopy reflectance readings at $830 \mathrm{~nm}$ conducted with an MRS5 multispectral radiometer at 82 DAP.

${ }^{x}$ Weight of pods from 2-m row length per plot. Average pod weight calculated from a 50-pod subsample. Pod yield components evaluated at 88 DAP.

y LSD $=$ least significant difference $(P=0.05)$; na $=$ not applicable when $P>0.05$. Degrees of freedom for all comparisons $=19$.

${ }^{\mathrm{z}} \mathrm{CV}(\%)=$ coefficient of variation.

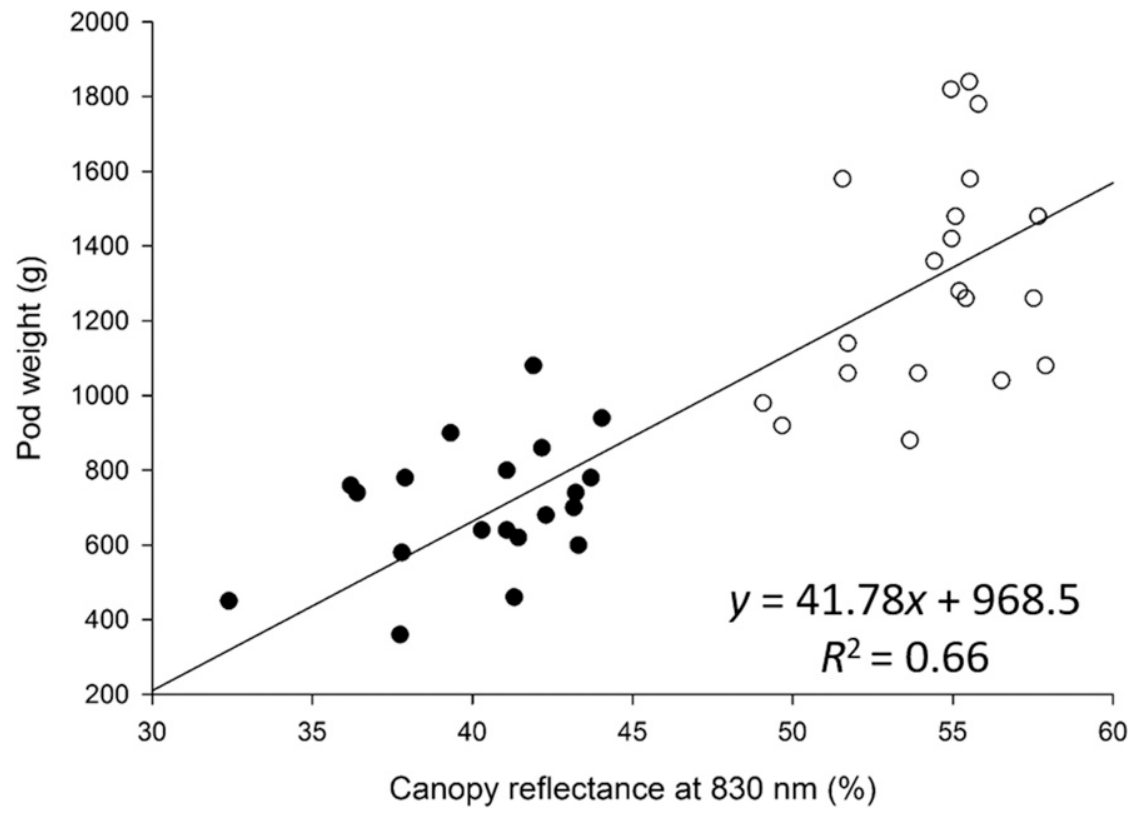

Fig. 1. Relationship between canopy reflectance at $830 \mathrm{~nm}(\%)$ and baby lima bean pod weight $(\mathrm{g})$ across varieties Cypress (๑) and 184-85 (O) at Pavilion, NY in 2016. 
Trials 1 and 2 (2015). In trials 1 and 2, application of fungicides regardless of treatment significantly reduced disease incidence by 54.5 to $57.3 \%$ compared with nontreated plots (Table 1). Moreover, disease incidence in plots receiving fungicides regardless of treatment was not significantly different between plots. The number of leaves per stem was significantly increased from all fungicide treatments by 54.2 to $116 \%$ compared with nontreated plots and was not significantly different between plots. In both trials, fungicide application had no significant effect on pod weight and the average weight of one pod (Table 1).

Table 3. Median runs analysis of tan spot epidemics on disease incidence collected in each of the transects within four baby lima bean fields in New York in 2015 and 2016

\begin{tabular}{|c|c|c|c|c|c|c|}
\hline \multirow[b]{2}{*}{ Year } & \multirow[b]{2}{*}{ Field (variety) } & \multirow[b]{2}{*}{ Transect } & \multicolumn{4}{|c|}{$Z^{\mathbf{z}}$} \\
\hline & & & 52 DAP & 78 DAP & 56 DAP & 80 DAP \\
\hline \multirow[t]{12}{*}{2015} & 1 (Cypress) & 1 & -1.56 & -1.88 & $\ldots$ & $\ldots$ \\
\hline & & 2 & -1.47 & -1.88 & $\ldots$ & $\ldots$ \\
\hline & & 3 & -0.01 & $-2.54^{*}$ & $\ldots$ & $\ldots$ \\
\hline & & 4 & 2.34 & -0.55 & $\ldots$ & $\ldots$ \\
\hline & & 5 & -1.76 & -0.68 & $\ldots$ & $\ldots$ \\
\hline & & 6 & -0.47 & -1.25 & $\ldots$ & $\ldots$ \\
\hline & 2 (Maestro) & 1 & -1.24 & -1.27 & $\ldots$ & $\ldots$ \\
\hline & & 2 & -0.93 & -0.61 & $\ldots$ & $\ldots$ \\
\hline & & 3 & -0.95 & -0.61 & $\ldots$ & $\ldots$ \\
\hline & & 4 & 0.01 & -1.81 & $\ldots$ & $\ldots$ \\
\hline & & 5 & 0.09 & -1.61 & $\ldots$ & $\ldots$ \\
\hline & & 6 & 0.19 & -1.83 & $\ldots$ & $\ldots$ \\
\hline \multirow[t]{8}{*}{2016} & 3 (Cypress) & 1 & $\ldots$ & $\ldots$ & $-4.11 *$ & $-2.19 *$ \\
\hline & & 2 & $\ldots$ & $\ldots$ & $-2.49 *$ & $-3.49 *$ \\
\hline & & 3 & $\ldots$ & $\ldots$ & $-3.67 *$ & $-1.84^{*}$ \\
\hline & & 4 & $\ldots$ & $\ldots$ & 0.35 & $-2.10^{*}$ \\
\hline & $4(184-85)$ & 1 & $\ldots$ & $\ldots$ & 2.41 & $-4.05^{*}$ \\
\hline & & 2 & $\ldots$ & $\ldots$ & 2.41 & $-4.05^{*}$ \\
\hline & & 3 & $\ldots$ & $\ldots$ & -0.74 & $-4.38^{*}$ \\
\hline & & 4 & $\ldots$ & $\ldots$ & -0.73 & $-4.73^{*}$ \\
\hline
\end{tabular}

${ }^{\mathrm{z}} Z$ statistics $=$ (observed number of runs - expected number of runs $) /$ standard deviation within each transect ( $n=40$ sampling units within each transect). Disease incidence $=($ number of leaves with at least one tan spot lesion/total number of leaves) $\times 100$ on each stem. $Z$ statistics less than -1.96 indicate significance at $P=0.05$ (indicated by an asterisk). $\mathrm{DAP}=$ days after planting.

Table 4. Spatial analysis of tan spot epidemics in grid matrices using median runs analyses and spatial analysis by distance indices within four baby lima bean fields in New York in 2015 and 2016

\begin{tabular}{lccc}
\hline $\begin{array}{l}\text { Field } \\
\text { (year) }\end{array}$ & $\begin{array}{c}\text { Days after } \\
\text { planting }\end{array}$ & $\begin{array}{c}\text { Number of rows with } \\
\text { aggregation }^{\mathbf{y}}\end{array}$ & $\boldsymbol{I}_{\boldsymbol{a}}(\boldsymbol{P}=)^{\mathbf{z}}$ \\
\hline $1(2015)$ & 52 & 3 & $3.91(0.0002)$ \\
& 78 & 9 & $3.09(0.0002)$ \\
$2(2015)$ & 52 & 2 & $1.51(0.0092)$ \\
& 78 & 8 & $1.55(0.0062)$ \\
$3(2016)$ & 56 & 1 & $1.22(0.1051)$ \\
& 80 & 10 & $3.54(0.0002)$ \\
$4(2016)$ & 56 & 1 & $1.55(0.0119)$ \\
& 80 & 10 & $2.51(0.0002)$ \\
\hline
\end{tabular}

y Number of total rows $(n=10)$ where $Z$ statistic was less than the -1.96 , indicating significance at $P=0.05$.

${ }^{\mathrm{z}}$ Index of aggregation $\left(I_{a}\right)$ obtained from spatial analysis by distance indices. Probability value displayed parenthetically.
Trials 3 and 4 (2016). In trials 3 and 4, fungicides also significantly reduced tan spot incidence by 76.1 to $88.3 \%$, regardless of treatment, compared with nontreated plots (Table 2). In trial 3, tan spot severity on leaves in plots receiving fungicides for pod disease control and all four applications (foliar + pod) was significantly less than in plots receiving only the earlier fungicides (foliar). Fungicide application also increased the number of leaves per stem compared with nontreated plots and was significantly higher in plots receiving all four applications (foliar + pod) than the other treatments. The number of leaves per stem increased by $17.9 \%$ when fungicides were applied for pod disease control compared with the earlier applications (foliar). Canopy reflectance at $830 \mathrm{~nm}$ was significantly increased by an average of $15 \%$ from application of fungicides, regardless of treatment, compared with nontreated plots (Table 2).

In trial 4, tan spot incidence and severity were not significantly different among the plots receiving fungicides and were reduced by an average of 83 and $73.5 \%$, respectively, compared with nontreated plots (Table 2). Fungicides also significantly increased the number of leaves per stem by $26.8 \%$ across all treatments compared with nontreated plots. The increase in the number of leaves produced on stems from fungicides did not translate into a significant effect on canopy reflectance at $830 \mathrm{~nm}$ (Table 2). In trials 3 and 4, fungicide application had no significant effect on the weight of pods and average weight per pod (Table 2).

The isolation frequency of $D$. americana associated with tan spot lesions within the nontreated plots in trials 1 and 2 was 78 and $84 \%$, respectively. B. exigua var. exigua was isolated from $35 \%$ of tan spot lesions only in trial 2 . In trials 3 and 4 , the incidence of $D$. americana associated with tan spot lesions was 72 and $68 \%$ and the incidence of B. exigua var. exigua was 45 and $52 \%$, respectively. Marginal necrotic lesions were also observed on leaves collected in both fields. These lesions did not have pycnidia and were associated with fungi belonging to the genera Alternaria, Ulocladium, and Cladosporium and considered likely to be secondary to abiotic damage.

Relationships between canopy reflectance and lima bean pod weight. Canopy reflectance at $830 \mathrm{~nm}$ was identified as the most significant predictor of baby lima bean pod weight. Relationships between all other single wavelengths $(485,560,550$, and $1,650 \mathrm{~nm})$ and lima bean pod weight were not significant $(P>0.05)$. All wavelength ratios were also not significant predictors of lima bean pod weight $(P>0.05)$ with the exception of $830 / 660$, which provided moderate predictive ability $\left(R^{2}=0.48\right)$. NDVI and DVI were moderate predictors $\left(0.42<R^{2}<0.51\right)$ of lima bean pod weight but suboptimal compared with canopy reflectance at $830 \mathrm{~nm}$. A significant linear relationship was observed between canopy reflectance at $830 \mathrm{~nm}$ across the two varieties (Cypress and 184-85) and pod weight $(F=25.8 ; P<0.001)$, with good predictive value $\left(R^{2}=0.66\right.$; standard error of the estimate of $y=231$; Fig. 1).

Overall, canopy reflectance at $830 \mathrm{~nm}$ was $35 \%$ higher in trial 4 (184-85) than trial 3 (Cypress). These differences in canopy reflectance at $830 \mathrm{~nm}$ were also reflected in overall trends in pod weight between the two trials. For example, pod weight was $112.5 \%$ higher in trial 4 compared with trial 3 (Table 2). The average weight of one pod was not significantly different between varieties $(P=0.685)$.

Spatiotemporal characteristics of tan spot epidemics. Spatial analyses. Similar spatial patterns were observed in tan spot incidence across all fields (Tables 3 and 4). Tan spot incidence ranged from 8 to 15 and 55 to $80 \%$ at the first and second assessments, respectively. The incidence of tan spot was 37.2\% lower in 2016 (fields 3 and 4) than in 2015 (fields 1 and 2). In fields 1, 2, and 4, no evidence

Table 5. Spatiotemporal analysis of tan spot epidemics in grid matrices within baby lima bean fields in 2015 and 2016 in New York using the association function of spatial analysis by distance indices (Winder et al. 2001)

\begin{tabular}{lcccc}
\hline Field & Time periods (days after planting) & Actual sample size & Effective sample size & Overall association $(\boldsymbol{X})^{\mathbf{z}}$ \\
\hline 1 & 52 and 78 & 300 & 249.0 & $0.547(<0.0001)$ \\
2 & 52 and 78 & 300 & 142.7 & $0.189(0.0111)$ \\
3 & 56 and 80 & 410 & 200.8 & $0.282(<0.0001)$ \\
4 & 56 and 80 & 410 & 279.7 & $0.574(<0.0001)$ \\
\hline
\end{tabular}

${ }^{\mathrm{z}}$ Overall association. Associated probability values calculated using a two-tail test indicated in parentheses. 
was found for aggregation of tan spot in transects at the first assessments. However, at the second assessments, aggregation was detected in $16.7 \%$ of transects in field $1,75 \%$ of transects in field 3 , and all transects in field 4 . In field 2, the spatial pattern of tan spot was random in all transects at both times (Table 3).

A temporal trend toward an increasing frequency of spatial aggregation of tan spot was also depicted in the grid matrices (Table 4). For example, in fields 1 and 2, the frequency of rows with significant $(P<0.05)$ spatial aggregation using median runs analyses increased three- and fourfold between 52 and 78 DAP. In fields 3 and 4, the frequency of rows with significant $(P<0.05)$ spatial aggregation increased 10-fold between 56 and 80 DAP. Random spatial distributions of tan spot incidence were suggested at the first assessment in field 1 in 2015 and in both fields in 2016. In all fields, SADIE provided evidence for aggregation at the final assessment (Table 4).

Spatiotemporal analyses. Significant $(P<0.001)$ spatial associations were detected between the local clustering indices at successive assessments in all fields. This finding suggested that the spatial pattern depicted at the final assessments (78 and 80 DAP) was associated with the spatial position of diseased stems at the earlier assessments (Table 5).

\section{Discussion}

This study provided new insights into the quantitative epidemiology and crop losses associated with tan spot epidemics affecting baby lima bean crops in New York. The low incidence and severity of tan spot soon after crop emergence and the predominantly random spatial distribution of disease incidence depicted in the early portion of the epidemic do not accurately indicate whether the inoculum was more likely to have originated from within or outside fields of interest. However, the relatively rapid spread of tan spot within fields and the disease incidence at harvest suggests multiple infection cycles that typify polycyclic epidemics (Madden et al. 2007) that derive from local, small-scale aggregation and short-range dispersal of inoculum.

Minimal evidence was found for the role of inoculum sources from outside the field of interest due to significant spatiotemporal associations between spatial patterns of tan spot incidence in the grid matrices in all fields. The initially random distribution of disease early in the season may derive from a range of modes of pathogen introduction. These may include the arrival of ascospores via wind from an associated teleomorph, diseased seedlings, or a within-field source of inoculum such as infested soil, plant debris, or an alternative host. The teleomorphs of D. americana and B. exigua var. exigua have not been described, discounting the potential role of ascospores for epidemic initiation through relatively frequent foci. The probability of foci initiated from diseased seedlings is also discounted, because all baby lima bean seed used to establish fields in New York is fungicide treated (M. Gardinier, personal communication). Little is known of the biology of D. americana and B. exigua var. exigua other than that they are considered cosmopolitan pathogens that may survive saprophytically on a range of crop residues and in soils, and are generally considered relatively weak pathogens (Aveskamp et al. 2009; Bardas et al. 2008; Chen et al. 2015; Y. P. Li et al. 2012). In western New York, severe thunderstorm activity is frequent in early spring, often bearing hail and wind-blown rain, and causing low-level flooding. In most years, frequent spring rains from these storms negated the need for irrigation infrastructure in broad-acre cropping systems but were often accompanied by crop damage. Anecdotal, regular observations of epidemics in commercial fields suggested initiation of tan spot following splashing and sticking of soil onto the lower leaves of plants or abiotic injury such as hail damage. We suspect that baby lima bean is highly susceptible to both pathogens and initial infection by the fungi may be facilitated by injury to the host plant. The cosmopolitan nature and ability to exploit wounds for infection has been previously noted for B. exigua var. exigua in multiple bean species and potato (Boerema and Howeler 1967; Domsch et al. 1980; Morgan-Jones and Burch 1988).

The high isolation frequencies of pycnidial fungi observed in tan spot lesions and the ability to reduce disease incidence and defoliation from application of single-site fungicides reconfirmed the dominance of tan spot in the foliar disease complex affecting baby lima bean in western New York (Gorny et al. 2015, 2016). Surveys of additional baby lima bean fields in western New York in 2015 identified a low $(<10 \%)$ frequency of bacterial brown spot caused by Pseudomonas syringae pv. syringae (Beach 1892; Tisdale and Williamson 1923), which was not observed in 2016. Colletotrichum spp. were observed on distinctive necrotic lesions lacking a tan center in an additional field (variety Kingston) in 2015 at low incidence (S. J. Pethybridge, unpublished data). Anthracnose caused by Colletotrichum lindemuthianum is a severe disease of common, snap, and lima bean (Dillard and Cobb 1993; Ntahimpera et al. 1997). Despite the low prevalence of this disease at this time, further work should identify this fungus to species and fulfill Koch's postulates if necessary. Therefore, the potential for other pathogens to contribute to the foliar disease complex is substantial and requires careful characterization of symptoms and further disentangling of their importance. Interestingly, despite the importance of white mold in the western New York production system (Lehner et al. 2017) and lima bean production elsewhere, in these trials, the incidence of white mold was negligible $(<0.01 \%)$. Moreover, gray mold caused by Botrytis cinerea was not observed.

Historical rationale for fungicide application for tan spot control in baby lima bean fields in New York was to reduce disease to maximize yield in a crop that was rapidly expanding in production area to meet increasing demand. The fungicides (boscalid and pyraclostrobin) registered for foliar and pod disease control in baby lima bean in New York were found to be highly efficacious at reducing the incidence of tan spot and preventing defoliation. The resultant increase in green leaf area was detected through canopy reflectance at $830 \mathrm{~nm}$ and the average number of leaves per stem. However, baby lima bean is a highly competitive crop and the lack of yield improvement from significant increases in green leaf and across varieties suggests a highly plastic relationship. For example, in 2016, green leaf area was $45.7 \%$ higher in nontreated plots within trial 4 (184-85) than trial 3 conducted in an adjacent Cypress block in the same field. This finding suggests that baby lima bean production in western New York can endure substantial defoliation from foliar disease without yield penalty. Lima bean yield has been shown to be strongly related to pod disease and environmental conditions over flowering, influencing the number of pods retained to harvest (Fisher and Weaver 1974; Wootten 1992), and not related to agronomic factors leading to enhanced light interception such as narrow row spacing and plant population density (Sankula et al. 2001; Sirait et al. 1994). Thus, the need for fungicides for tan spot control in baby lima bean in New York over the vegetative growth phase can be discounted. Reduced fungicide application will lead to increased profitability and less environmental impact, and ease selection pressures on fungal pathogen populations such as the development of fungicide resistance. No information is available on the in vitro sensitivity of Boeremia exigua var. exigua and $D$. americana populations to the active ingredients of the fungicides registered for disease management in baby lima bean fields in New York. The resultant disease control from the application of fungicides in all small-plot, replicated trials suggested that populations of both fungi are likely to be sensitive to both FRAC 7 and 11 fungicides (Ishii and Holloman 2015).

Further research to optimize the baby lima bean production system in western New York should focus on pod disease control scheduling based on white mold risk modeling to encapsulate the role of edaphic and environmental factors in disease development documented in similar bean crops (Harikrishnan and del Rio 2008; Jones et al. 2012).

\section{Acknowledgments}

This research was supported by the United States Department of AgricultureNational Institute of Food and Agriculture Hatch project NYG-625424, managed by The New York State Agricultural Experiment Station, Cornell University, Geneva, NY; the Genesee Valley Regional Market Authority; and the New York Vegetable Research Association and Council. We thank S. Nelson (University of Hawaii at Manoa, Honolulu) for constructive comments on an earlier manuscript draft; C. Bowden, E. Maloney, D. Strickland, and M. Call for their technical support; growers R. L. Jeffres and Sons, Harris Farms, and Gary Swede Farms for collaboration to enable on-farm trials; and M. Gardinier, R. Ward, and 
B. Lowe (Farm Fresh First LLC, Oakfield, NY) for their assistance and constructive discussion.

\section{Literature Cited}

Anderson, T. W., and Darling, D. A. 1954. A test of goodness of fit. J. Am. Stat. Assoc. 49:765-769.

Aveskamp, M. M., Verkley, G. J. M., de Gruyter, J., Murace, M. A., Perelló, A., Woudenberg, J. H. C., Groenewald, J. Z., and Crous, P. W. 2009. DNA phylogeny reveals polyphyly of Phoma section, Peyronellaea and multiple taxonomic novelties. Mycologia 101:363-382.

Bardas, G. A., Tziros, G. T., and Tzavella-Klonari, K. 2008. First report of Ascochyta leaf spot caused by Phoma exigua var. exigua on common bean in Greece. Plant Dis. 92:653.

Beach, S. A. 1892. Blight of lima beans. N. Y. Agric. Exp. Stn. Bull. 48:331.

Boerema, G. H., and Howeler, L. H. 1967. Phoma exigua Desm. and its varieties. Persoonia 5:15-28.

Broge, N. H., and Leblanc, E. 2001. Comparing prediction power and stability of broadband and hyperspectral vegetation indices for estimation of green leaf area index and canopy chlorophyll density. Remote Sens. Environ. 76: 156-172.

Chen, Q., Jiang, J. R., Zhang, G. Z., Cai, L., and Crous, P. W. 2015. Resolving the Phoma enigma. Stud. Mycol. 82:137-217.

Daughtry, C. S. T., Vanderbilt, V. C., and Pollara, V. J. 1982. Variability of reflectance measurements with sensor altitude and canopy type. Agron. J. 74: 744-750.

Dillard, H. R., and Cobb, A. C. 1993. Survival of Colletotrichum lindemuthianum in bean debris in New York State. Plant Dis. 77:1233-1238.

Domsch, K. H., Gams, W., and Anderson, T. H. 1980. Compendium of Soil Fungi, Vol. 1. Academic Press, New York.

Dutilleul, P., Clifford, P., Richardson, S., and Hemon, D. 2008. Modifying the t-test for assessing the correlation between two spatial processes. Int. Biom. Soc. 49:305-314

Evans, L. T., and Fischer, R. A. 1999. Yield potential: Its definition, measurement and significance. Crop Sci. 39:1544-1551.

Evans, T. A., Mulrooney, R. P., Gregory, N. F., and Kee, E. 2007. Lima bean downy mildew: Impact, etiology and management strategies for Delaware and the Mid-Atlantic region, U. S. Plant Dis. 91:128-135.

Everts, K. L., Collins, A. A., and Armentrout, D. K. 2002. Evaluation of foliar fungicides for managing white mold on lima beans near Harbeson, DE, 2002. Plant Dis. Manage. Rep. 58:V031.

Everts, K. L., and Zhou, X. G. 2004. Evaluation of fungicides for control of white mold on lima beans, 2004. Plant Dis. Manage. Rep. 60:V108.

Everts, K. L., and Zhou, X. G. 2007. Control of white mold and web blight on lima bean grown for processing. (Abstr.) Phytopathology 97:S174.

Fisher, V. J., and Weaver, C. K. 1974. Flowering, pod set, and pod retention of lima bean in response to night temperature, humidity and soil moisture. J. Am. Soc. Hortic. Sci. 90:448-450.

Gamon, J. A., and Surfus, J. S. 1999. Assessing leaf pigment content and activity with a reflectometer. New Phytol. 143:105-117.

Gibbons, J., and Chakraborti, S. 2010. Nonparametric Statistical Inference. Chapman and Hall/CRC Press, Boca Raton, FL.

Gorny, A. M., Kikkert, J. R., Dunn, A. R., Dillard, H. R., Smart, C. D., and Pethybridge, S. J. 2015. Tan spot of lima bean caused by Boeremia exigua in New York State. Can. J. Plant Pathol. 37:523-528.

Gorny, A. M., Kikkert, J. R., Shivas, R. G., and Pethybridge, S. J. 2016. First report of Didymella americana on lima bean (Phaseolus lunatus). Can. J. Plant Pathol. 38:389-394.

Grinbergs, D., France, A., and Varrelmann, M. 2016. First report of Boeremia exigua var. exigua (syn. Phoma exigua var. exigua) causing black root rot on industrial chicory (Cichorium intybus var. sativum) in Chile. Plant Dis. 100: 2328.

Guan, J., and Nutter, F. W., Jr. 2001. Factors affecting the quality and quantity of sunlight reflected from alfalfa canopies. Plant Dis. 85:865-874.

Guan, J., and Nutter, F. W., Jr. 2004. Comparison of single-point alfalfa yield models based on visual disease intensity and remote sensing assessments. Can. J. Plant Pathol. 26:314-324.

Gutiérrez-Rodriguez, M., Escalante-Estrada, J. A., Rodriguez Gonazalex, M. T., and Reynolds, M. P. 2006. Canopy reflectance indices and its relationship with yield in common bean plants (Phaseolus vulgaris L.) with phosphorus supply. Int. J. Agric. Biol. 8:202-207.

Harikrishnan, R., and del Rio, L. E. 2008. A logistic regression model for predicting risk of white mold incidence on dry bean in North Dakota. Plant Dis. 92:42-46.

Hughes, G. 1987. Spatial heterogeneity in crop loss assessment models. Phytopathology 78:883-884.

Hughes, G. 2017. The evidential basis of decision making in plant disease management. Annu. Rev. Phytopathol. 55:41-59.

Hughes, G., and Madden, L. V. 1992. Aggregation and incidence of disease. Plant Pathol. 41:657-660.

Hughes, G., and Madden, L. V. 1993. Using the beta-binomial distribution to describe aggregated patterns of disease incidence. Phytopathology 83: 759-763.
Irinyi, L., Kövics, G. J., and Sándor, E. 2009. Taxonomical re-evaluation of Phoma-like soybean pathogenic fungi. Mycol. Res. 113:249-260.

Ishii, H., and Holloman, D. W., eds. 2015. Fungicide Resistance in Plant Pathogens. Springer, Tokyo.

James, W. C., and Teng, P. S. 1979. The quantification of production constraints associated with plant diseases. Adv. Appl. Biol. 4:201-267.

Johnson, K. B. 1987. Defoliation, disease, and growth: A reply. Phytopathology 77:1495-1497.

Jones, S. J., Gent, D. H., Pethybridge, S. J., and Hay, F. S. 2012. Site-specific risk factors of white mould epidemics in bean (Phaseolus vulgaris) in Tasmania Australia. N. Z. J. Crop Hortic. Sci. 40:147-159.

Jones, S. J., Hay, F. S., Harrington, T. C., and Pethybridge, S. J. 2011. First report of Boeremia blight caused by Boeremia exigua var. exigua on pyrethrum in Australia. Plant Dis. 95:1478.

Kee, W. E., Jr., Glancey, J. L., and Wootten, T. L. 1997. The lima bean: A vegetable crop for processing. HortTechnology 7:119-128.

Kness, A. A., Johnson, G., Everts, K. L., Evans, T. A., Donofrio, N. M., and Earnest E. G. 2016. Managing pod rot of lima bean caused by Phytophthora capsici with fungicides in the mid-Atlantic region. Plant Health Prog. 17:130-132.

Lehner, M., Kikkert, J. R., Gugino, B., and Pethybridge, S. J. 2017. Fungicide sensitivity and efficacy of boscalid, fluazinam and thiophanate-methyl for white mold control in snap bean. Plant Dis. 101:1253-1258.

Li, B., Madden, L. V., and Xu, X. 2012. Spatial analysis by distance indices: An alternative local clustering index for studying spatial patterns. Methods Ecol. Evol. 3:368-377.

Li, L., Zhang, Q., and Huang, D. 2014. A review of imaging techniques for plant phenotyping. Sensors (Basel) 14:20078-20111

Li, Y. P., You, M. P., Finnegan, P. M., Khan, T. N., Vanoiselet, V., Eyres, N., and Barbetti, M. J. 2012. First report of black spot caused by Boeremia exigua var. exigua on field pea in Australia. Plant Dis. 96:148.

Ma, B. L., Dwyer, L. M., Cober, E. R., and Morrison, M. J. 2001. Early prediction of soybean yield from canopy reflectance measurements. Agron. J. 93:1227-1234.

Madden, L. V. 1989. Dynamic nature of within-field disease and pathogen distributions. Pages 96-126 in: Spatial Components of Plant Disease Epidemics. M. J. Jeger, ed. Prentice-Hall, Englewood Cliffs, NJ.

Madden, L. V., and Hughes, G. 1994. BBD-computer software for fitting the betabinomial distribution to disease incidence data. Plant Dis. 78:536-540.

Madden, L. V., and Hughes, G. 1995. Plant disease incidence: Distributions, heterogeneity, and temporal analysis. Annu. Rev. Phytopathol. 33:529-564.

Madden, L. V., and Hughes, G. 1999. An effective sample size for predicting plant disease incidence in a spatial hierarchy. Phytopathology 89:770-781.

Madden, L. V., Hughes, G., and van den Bosch, F. 2007. The Study of Plant Disease Epidemics. American Phytopathological Society, St. Paul, MN.

Madden, L. V., Louie, R., Abt, J. J., and Knoke, J. K. 1982. Evaluation of tests for randomness of infected plants. Phytopathology 72:195-198.

Marcinkowska, J., Roze-Kałużny, I., and Kałużny, W. 2005. Pathogenicity of some Phoma exigua var. exigua isolates. Phytopathol. Pol. 38:35-44.

Markowski, C. A., and Markowski, E. P. 1990. Conditions for the effectiveness of a preliminary test of variance. Am. Stat. 44:322-326

McRoberts, N., Hughes, G., and Savary, S. 2003. Integrated approaches to understanding and control of diseases and pests in field crops. Australas. Plant Pathol. 32:167-180.

Morgan-Jones, G., and Burch, K. B. 1988. Studies in the genus Phoma XIII. Concerning Phoma exigua var. exigua, a cosmopolitan, ubiquitous fungus on diseased and dead plant material. Mycotaxon 32:477-490.

Nilsson, H.-E. 1995. Remote sensing and image analysis in plant pathology. Annu. Rev. Phytopathol. 33:489-528.

Ntahimpera, N., Dillard, H. R., Cobb, A. C., and Seem, R. C. 1997. Influence of tillage practices on anthracnose development and distribution in dry bean fields. Plant Dis. 81:71-76.

Passioura, J. 2006. Increasing crop productivity when water is scarce - from breeding to field management. Agric. Water Manage. 80:176-196.

Perry, J. N. 1995. Spatial analysis by distance indices. J. Anim. Ecol. 64:303-314

Perry, J. N. 1998. Measures of spatial pattern for counts. Ecology 79:1008-1017.

Perry, J. N., Winder, L., Holland, J. M., and Alston, R. D. 1999. Red-blue plots for detecting clusters in count data. Ecol. Lett. 2:106-113.

Pethybridge, S. J., and Nelson, S. C. 2015. Leaf Doctor: A new application for assessing disease severity. Plant Dis. 99:1310-1316.

Sankula, S., VanGessel, M. J., Kee, W. E., Edward Beste, C., and Everts, K. L. 2001. Narrow row spacing does not affect lima bean yield or management of weeds and other pests. HortScience 36:884-888.

Savary, S., Teng, P. S., Willocquet, L., and Nutter, F. W., Jr. 2006. Quantification and modeling of crop losses: A review of purposes. Annu. Rev. Phytopathol. 44:89-112.

Sirait, Y., Pill, W. G., and Kee, W. E., Jr. 1994. Lima bean (Phaseolus lunatus L.) response to irrigation regime and plant population density. HortScience 29:71-73.

Soltani, A., and Sinclair, T. R., eds. 2012. Modeling Physiology Of Crop Development, Growth and Yield. CAB International, Cambridge, MA.

Tisdale, W. B., and Williamson, M. M. 1923. Bacterial spot of lima bean. J. Agric Res. 25:141-156

Turechek, W. W., and Madden, L. V. 1999a. Spatial pattern analysis of strawberry leaf blight in perennial production systems. Phytopathology 89:421-433. 
Turechek, W. W., and Madden, L. V. 1999b. Spatial pattern analysis and sequential sampling for the incidence of leaf spot on strawberry in Ohio. Plant Dis. 83: 992-1000.

Turechek, W. W., Madden, L. V., Gent, D. H., and Xu, X.-M. 2011. Comments regarding the binary power law for heterogeneity of disease incidence. Phytopathology 101:1396-1407.

Turechek, W. W., and McRoberts, N. 2013. Considerations of scale in the analysis of spatial pattern of plant disease epidemics. Annu. Rev. Phytopathol. 51:453-472.
USDA-NASS. 2016. Online publication. United States Department of Agriculture National Agriculture Statistics Service. https://quickstats.nass.usda.gov/

Walter, A., Liebisch, F., and Hund, A. 2015. Plant phenotyping: From bean weighing to image analysis. Plant Methods 11:14.

Winder, L., Alexander, C. J., Holland, J. M., Woolley, C., and Perry, J. N. 2001 Modelling the spatio-temporal response of predators to transient prey patches in the field. Ecol. Lett. 4:568-576.

Wootten, T. 1992. The search for improved lima beans yields: A starting point HortScience 27:1161. 